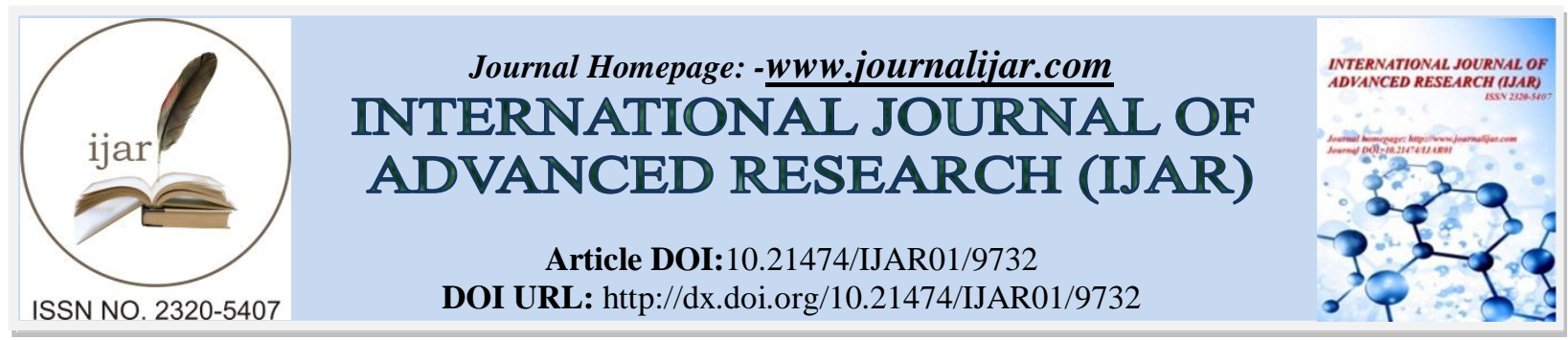

RESEARCH ARTICLE

\title{
DETERMINATION OF SOME HEAVY METALS POLLUTANTS IN SOIL SAMPLES COLLECTED FROM ATBARA CITY-SUDAN.
}

Sumia Ahmed ${ }^{1}$,Eljali Elhassan ${ }^{2}$, Huda Mohammed ${ }^{3}$ and Nezar Mohmoud ${ }^{4}$.

1. Associate Professor, Chemistry Department, Faculty of Education, Nile Valley University, Sudan.

2. Associate Professor, Chemistry Department, Faculty of Education, Khartoum University, P.O.Box406 Omdurman-Sudan.

3. Technician, Chemistry Department, Faculty of Education, Nile Valley University, Sudan.

4. ICM 120831 Our Lady's Hospital Navan Ireland.

\section{Manuscript Info}

Manuscript History

Received: 12 July 2019

Final Accepted: 14 August 2019

Published: September 2019

Key words:-

heavy metals ,X- Ray Fluorescence (XRF),Soil Pollution.

\section{Abstract}

The present study was conducted to evaluate the pollution level by some heavy metals in four sites at Atbara city, Sudan, include Atbara Railway Station (ARS), Atbara Railway Workshop (ARW), Atbara Industrial Area (AIA) and Eldaman Complex Foundry (ECF). Soil samples were collected from the study areas and from area which is expected to be free from industrial emissionto serve as control.Samples were analyzed for heavy metals $(\mathrm{Fe}, \mathrm{Cu}, \mathrm{Mn}, \mathrm{Cr}, \mathrm{Ni}, \mathrm{Pb}, \mathrm{Zn}$ and $\mathrm{V})$ by using x-ray Fluorescence. The data were treated statistically by correlation coefficient and multivariate analysis such as cluster analysis. The results indicated that the mean concentration of these metals in all areas of the study were higher than in the control area except Fe,this refer to anthropogenic activities for all areas. Also the results showed that metals $(\mathrm{Pb}, \mathrm{Zn}, \mathrm{Cr}, \mathrm{Ni}, \mathrm{V}, \mathrm{Mn}$ and $\mathrm{Cu})$ were derived from anthropogenic sources, (V, $\mathrm{Mn}$ and $\mathrm{Cu}$ ) as originating from mixed (anthropogenic and natural) sources and Fe from natural source.

Copy Right, IJAR, 2019,. All rights reserved.

\section{Introduction:-}

Pollution may be defined as the introduction by man into the environment of substances or energy liable to cause hazards to human health, harm to living resource and ecological system $\{1\}$. Soil is the critically environmental medium, which is subjected to a number of pollutants due to different human activities $\{2\}$. The soil will be polluted as a result of different human activities. Most of these pollutions are caused by vehicle accident which moves contaminants. The other pollutants, which cause soil pollution, include cars, trucks and airplanes that do not move the waste rather, they carry materials like fuel which can cause soil pollution as a result of pouring and emitting them from the vehicle. Dumping of toxic substances like different types of solvents, colored materials and detergents will extend earth and soil pollution $\{3\}$. Due to the many anthropogenic activities in industrial areas soil may get polluted which may cause major heavy metal contamination and which is more responsible for increasing the pollutants in the soil. Municipal sewage water, industrial effluents and many unwanted wastes like plastic materials, bottles, broken pieces of metal etc $\{4\}$. Soil contamination by heavy metals is a major concern because at high concentration they can harm on human life and the environment $\{5\}$. Fall of heavy elements and radioactive from the atmosphere to the earth, including combustion of fossil fuels, exhaust of automobiles, burning of wastes

Corresponding Author:-Sumia Mohamed.

Address:-Associate Professor, Chemistry Department, Faculty of Education, Nile Valley University, 
and garbage, radioisotopes as result of reactor accidents and vast firing, is only one way of chemical contamination of the soil $\{3\}$.Heavy metal contamination of soil result from anthropogenic as well as natural activities. Anthropogenic activities such as mining, smelting operation and agriculture have locally increased the levels of heavy metals such as $\mathrm{Cd}, \mathrm{Co}, \mathrm{Cr}, \mathrm{Pb}, \mathrm{As}$ and $\mathrm{Ni}$ in soil up to dangerous levels. Heavy metals are persistent in nature, therefore get accumulated in soils and plants $\{6,7\}$. Heavy metal pollution has become a serious health concern in recent years, because of industrial and agricultural development $\{8\}$. Problem of pollution from heavy metals has caused increasing alarmed. This applies to both industrialized zone and highly technological populated areas. Therefore the problem of pollution from heavy metals involves the whole population and regard all three receiving compartments namely, air, water and soil $\{9\}$.In the world several studies have been made bya number of researchers for determining heavy metal levels in contaminated soil $\{10,11\}$.In Omdurman industrial area the investigator $\{12\}$ showed that, $\mathrm{Ni}, \mathrm{Cu}$ and $\mathrm{Pb}$ are the major emitted elements. The study of $\{13\}$ evaluated the soil pollution with heavy metals for 40 surface and sub-surface soil samples from various locations to cover the area of Nyala city, Sudan.Theirreslts indicated that all the samples analyzed are safe in general for the toxicity levels .

The objectives of the present study to investigate the level of heavy metals including ( $\mathrm{Fe}, \mathrm{Cu}, \mathrm{Mn}, \mathrm{Cr}, \mathrm{Ni}, \mathrm{Pb}, \mathrm{Zn}$ and V) in surface soil samples collected from four different sites in Atbara City and to compare them with another site expected to be free from industrial emission,to serve as control.

\section{Material s and methods:-}

\section{The Study Site:}

This study took place inAtbaracity at Railwayworkshop(ARW), Railway station (ARS),Eldaman complex foundry(ECF) and industrial area (AIA).Atbara is located in the River Nile state in northernSudan .figure (2-1). It is located at the junction of theriver Nile with river Atbara.It is known as the railway city where the railway headquarters there.

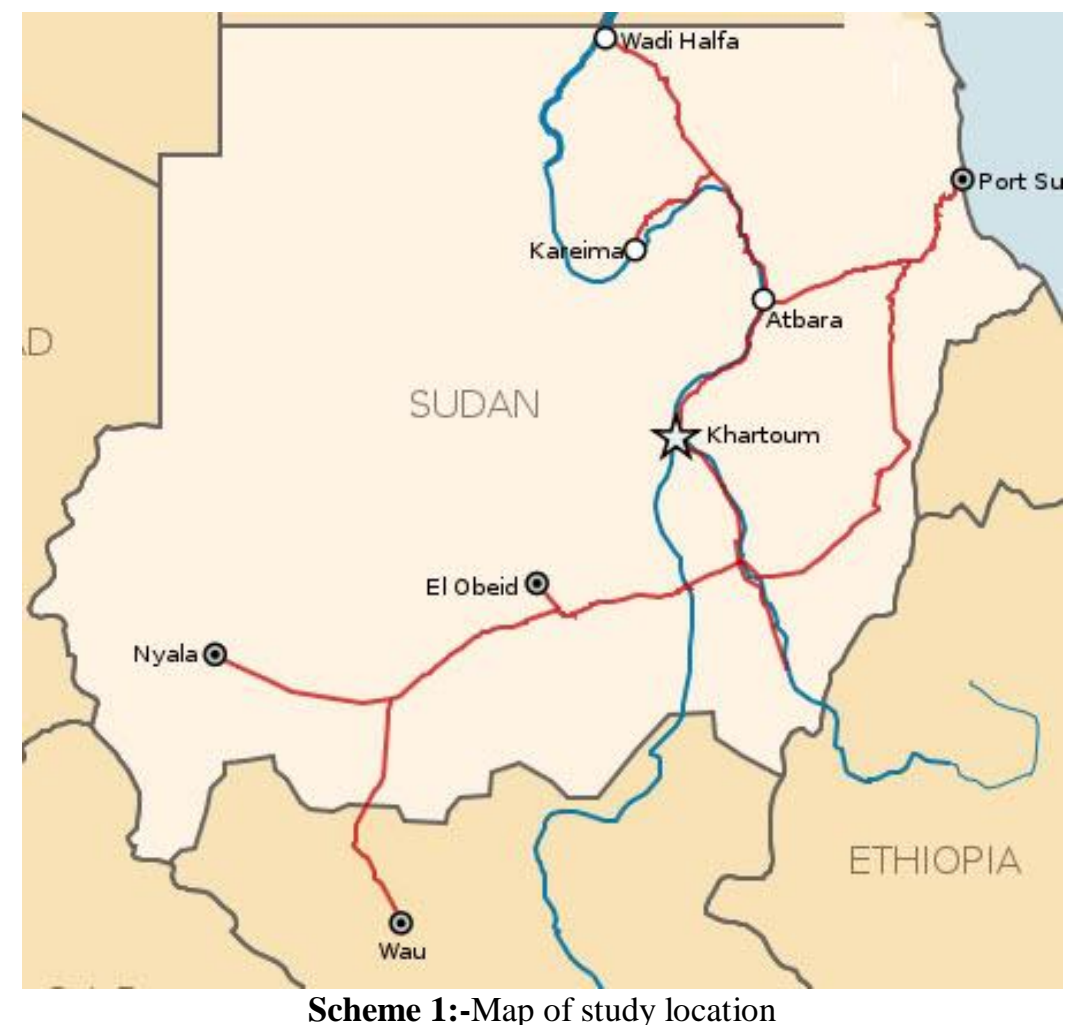

\section{Samples Collection and Pretreatment:}

Sampling sites were chosen with anthropogenic sources of heavy metals. Surface soil samples were collected from the area ofthe study and other surface soil samples were collected from area which is expected to be free from industrial emission to serve as control. All samples were collected with polyethylene spoon and stored in plastic bags. These samples were air dried and ground to soft powerand transported to laboratory for analysis. 


\section{Heavy Element Measurement:}

The XRFsystem used in this study was X-MET5000 system (oxford instrument).Dry clean and homogenous soil sample was placed in to plastic sample bag. This bag was placed on back ground plate to minimize radiation scatter and to provide constant back ground signal.Thestandardwereprepared in similar way.Theconcentrationof metals were measured directly by holed analyzer at right angles to the samples. The time of collection was 5 second.

The X-MET model 5000 is hand-held elemental analyzers intended for various different applications figure (2).Example applicationinclude: metal alloy analysis, soil and mining analysis, and electronic industry application. The X-MET5000 series analyzers are based on energy dispersive x-ray fluorescence technology and uses an x-ray tube as the source of excitation. The standard material is Rhodium.The analyzer contains a high Resolution PentaPIN diode detector.The X-MET provides a method for chemical analysis or samples identification (sorting) directly from samples in various forms. The instrument in a fully portable analyzer with anIntegrated PDA(Personal Digital Assistant) computer.Within the X-MET analysis program, the user may select analytical modes, view spectra and save data.

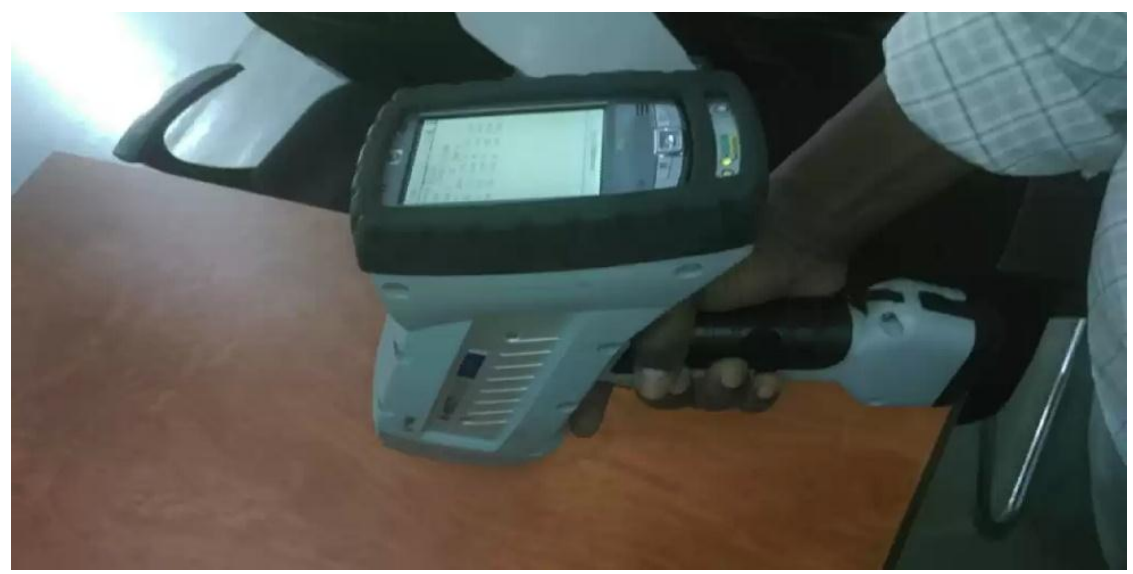

Figure 1:-Shape of X-MET5000 Instrument

\section{Results and Discussion:-}

Summary of statistical results for heavy elements concentration in soil samples from each area of the study and control area by XRF are in tables (1 to 2).

Table 1:-Summary ofstatistical results for total elements concentration from all areas of the study in ppm:

\begin{tabular}{|c|c|c|c|c|c|c|c|c|}
\hline & $\mathrm{Fe}$ & $\mathrm{Cu}$ & $\mathrm{Mn}$ & $\mathrm{Cr}$ & $\mathrm{Ni}$ & $\mathrm{Pb}$ & $\mathrm{Zn}$ & V \\
\hline Mean & 20.00 & 20.00 & 20.00 & 20.00 & 20.00 & 20.00 & 20.00 & 20.00 \\
\hline Median & $\begin{array}{c}872520.0 \\
0 \\
\end{array}$ & 19330.00 & $\begin{array}{c}11625.0 \\
0 \\
\end{array}$ & $\begin{array}{c}1075.0 \\
0 \\
\end{array}$ & 3010.00 & 80.00150 & 105.00175 & 4755.00 \\
\hline $\begin{array}{c}\text { Std. } \\
\text { Deviatio } \\
\text { n }\end{array}$ & $\begin{array}{c}882150.0 \\
0\end{array}$ & 10000.00 & 9950.00 & $\begin{array}{c}1100.0 \\
0\end{array}$ & 2750.00 & $\begin{array}{ll}0 & 00\end{array}$ & 00 & 4900.00 \\
\hline $\begin{array}{c}\text { Minimu } \\
\mathrm{m}\end{array}$ & $\begin{array}{c}54449.39 \\
3 \\
\end{array}$ & $\begin{array}{c}37583.28 \\
4 \\
\end{array}$ & $\begin{array}{c}7813.61 \\
0\end{array}$ & $\begin{array}{c}764.93 \\
9 \\
\end{array}$ & $\begin{array}{c}2254.56 \\
3 \\
\end{array}$ & $\begin{array}{c}206.72829 \\
9\end{array}$ & $\begin{array}{c}233.33877 \\
0\end{array}$ & $\begin{array}{c}2918.62 \\
9\end{array}$ \\
\hline $\begin{array}{c}\text { Maximu } \\
\mathrm{m}\end{array}$ & $\begin{array}{c}700100.0 \\
0 \\
\end{array}$ & $\begin{array}{llll}0 & 0 & 0\end{array}$ & 300.00 & 100.00 & 100.00 & . $\begin{array}{lll}0 & 0 & 0\end{array}$ & $\begin{array}{llll}0 & . & 0 & 0\end{array}$ & $\begin{array}{lll}0.0 & 0\end{array}$ \\
\hline Sum & $\begin{array}{c}950600.0 \\
0\end{array}$ & $\begin{array}{c}174100.0 \\
0\end{array}$ & $\begin{array}{c}28800.0 \\
0\end{array}$ & $\begin{array}{c}2500.0 \\
0\end{array}$ & 6900.00 & 900.000 & 800.00 & 9000.00 \\
\hline
\end{tabular}

Table 2:-Summary of statistical results for total elements concentration from Control area in ppm:

\begin{tabular}{|c|c|c|c|c|c|c|c|c|}
\hline & $\mathrm{Fe}$ & $\mathrm{Cu}$ & $\mathrm{Mn}$ & $\mathrm{Cr}$ & $\mathrm{Ni}$ & $\mathrm{Pb}$ & $\mathrm{Zn}$ & $\mathrm{V}$ \\
\hline Mean & 885733.33 & 943.33 & 1553.33 & 120.00 & 140.00 & 33.33 & 100.00 & 1106.67 \\
\hline Median & 888000.00 & 800.00 & 1480.00 & 100.00 & 100.00 & .000 & 100.00 & 1150.00 \\
\hline
\end{tabular}




\begin{tabular}{|c|c|c|c|c|c|c|c|c|}
\hline $\begin{array}{c}\text { Std. } \\
\text { Deviation }\end{array}$ & 4188.476 & 404.516 & 613.297 & 43.589 & 163.707 & 57.735 & 100.00 & 596.182 \\
\hline Minimum & 880900.00 & 630.00 & 980.00 & 90.00 & 0.00 & 0.00 & 0.00 & 490.00 \\
\hline Maximum & 888300.00 & 1400.00 & 2200.00 & 170.00 & 320.00 & 100.00 & 200.00 & 1680.00 \\
\hline Sum & 885733.33 & 943.33 & 1553.33 & 120.00 & 140.00 & 33.33 & 100.00 & 1106.67 \\
\hline
\end{tabular}

The mean concentrations of all elementsin all areas of the study arehigherthanin control area except Fe.This is refer to anthropogenic sources ofth/.eseelements. The mean concentration of elements from all areas are shownblew in figure (1).

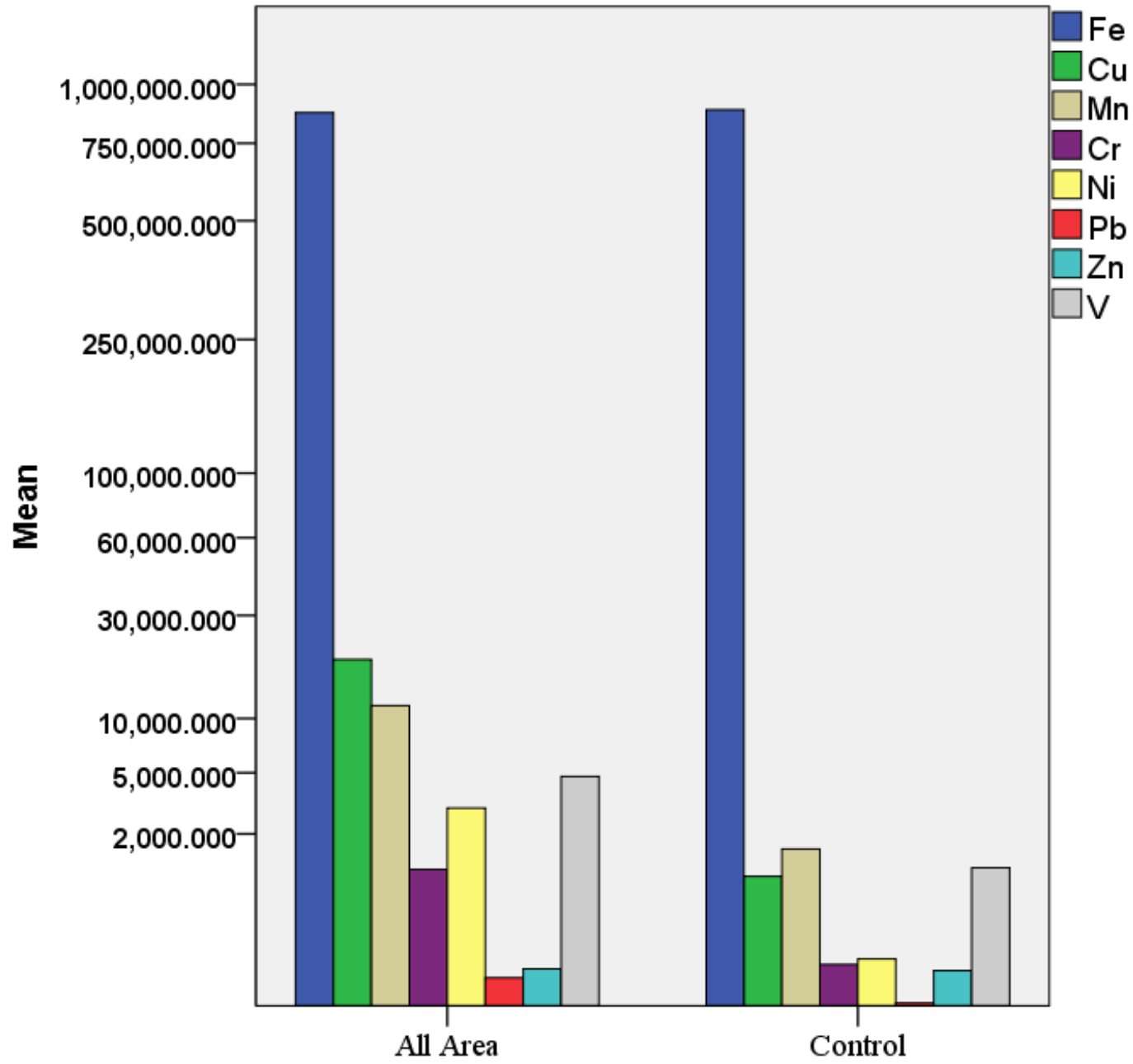

All Area \& Control

Figure 2:-The mean concentration of the elements in all areasof the study in ppm

\section{Correlation Matrices:}

Correlation analysis, which is one of the approaches of explore software, was used to achieve the similarity coefficients .Then it was used to assign the similarity of the samples (15).

Table 3:-TheCorrelations coefficientsbetweensomeelementsconcentrationinallareas:

\begin{tabular}{|c|c|c|c|c|c|c|c|c|}
\hline Element & $\mathrm{Fe}$ & $\mathrm{Cu}$ & $\mathrm{Mn}$ & $\mathrm{Cr}$ & $\mathrm{Ni}$ & $\mathrm{Pb}$ & $\mathrm{Zn}$ & $\mathrm{V}$ \\
\hline $\mathrm{Fe}$ & 1 & & & & & & & \\
\hline $\mathrm{Cu}$ & -.091 & 1 & & & & & & \\
\hline $\mathrm{Mn}$ & .075 & .022 & 1 & & & & & \\
\hline
\end{tabular}




\begin{tabular}{|c|c|c|c|c|c|c|c|c|}
\hline $\mathrm{Cr}$ & .145 & .223 & $.755^{* *}$ & 1 & & & \\
\hline $\mathrm{Ni}$ & .024 & .401 & .425 & .310 & 1 & & \\
\hline $\mathrm{Pb}$ & .039 & -.187 & $-.470^{*}$ & -.423 & -.429 & 1 & \\
\hline $\mathrm{Zn}$ & $-.510^{*}$ & -.166 & -.365 & -.300 & -.267 & .400 & 1 & \\
\hline $\mathrm{V}$ & -.052 & .385 & $.460^{*}$ & .291 & $.591^{* *}$ & $-.544^{*}$ & -.382 & 1 \\
\hline
\end{tabular}

Table(3) shows the correlation matrix of the heavy metals in the surface soils of all areas. The strongest correlation coefficient between Mn- Cr was (0.755)andMn, V was (0. 460). Ni and V formed another highly correlated pair with a correlation coefficient of $(0.591)$, suggesting they probably originated from some common sources. Negative stronger correlation between Fe-Zn was(-0.510), Mn $-\mathrm{Pb}$ was $(-0.470),(\mathrm{Pb}-\mathrm{V})$.

There was no significant correlation between $\mathrm{Cu}$ and $\mathrm{Zn}$.Strong correlations signify that each paired metals have commoncontamination sources.

\section{Multivariate Analysis for Soil Samples: \\ ClusterAnalysis :}

Cluster analysis was one of the multivariate analyses used in this studyto identify the relatively homogeneous groups of heavy metals. The hierarchical cluster analysis using nearest neighbor method produced twocluster,Figure (2).

The first cluster contained $(\mathrm{Pb}, \mathrm{Zn}, \mathrm{Cr}, \mathrm{Ni}, \mathrm{V}, \mathrm{Mn}$ and $\mathrm{Cu})$ these elements were classified as anthropogenic source .

The second cluster ( $\mathrm{Fe}, \mathrm{Mn}, \mathrm{Cu}$ and $\mathrm{V}$ ) indicated that $\mathrm{V}, \mathrm{Mn}$ and $\mathrm{Cu}$ as originating from mixed (anthropogenic and natural) sources andFefrom natural source.

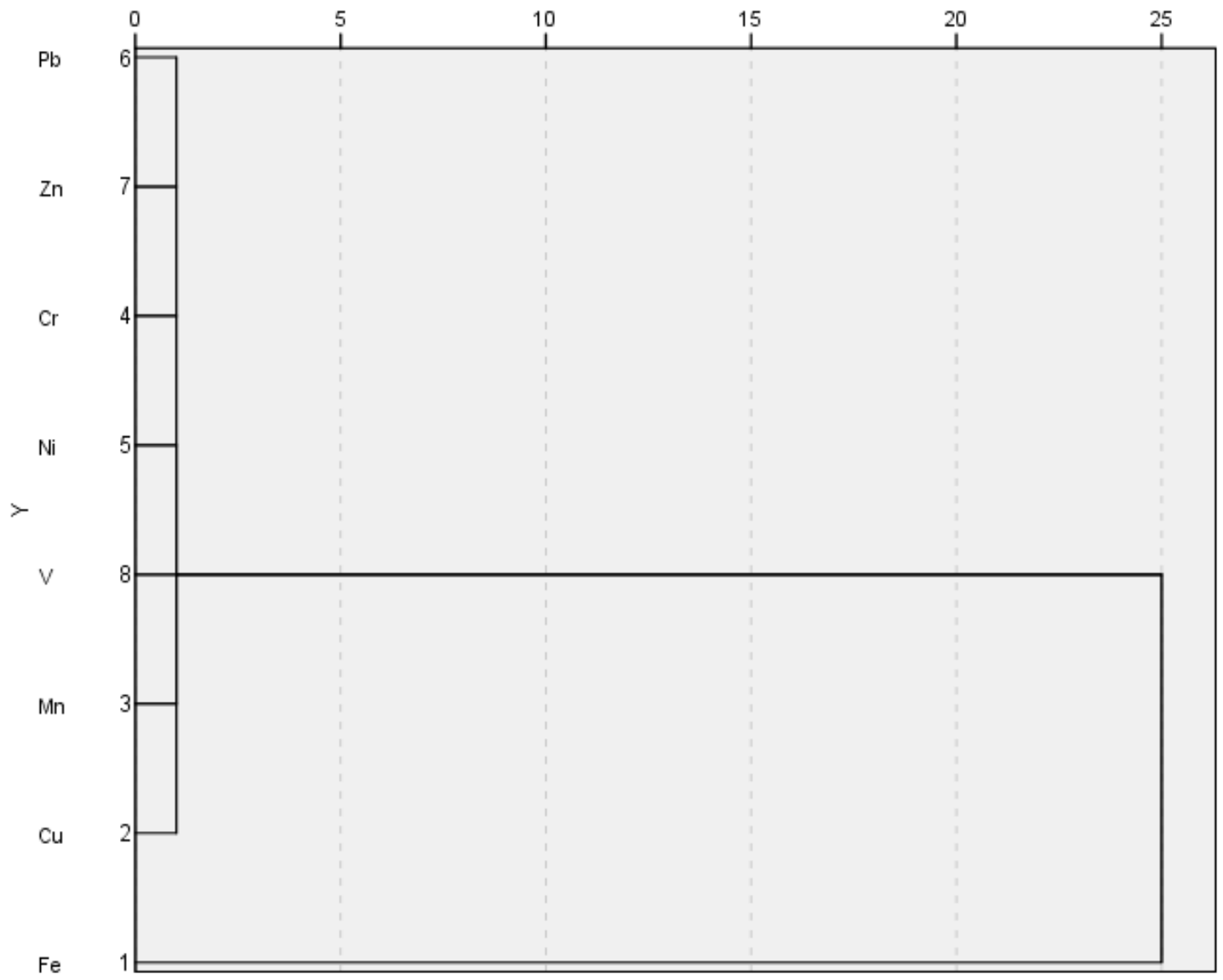

Figure 3:-Hierarchical cluster analysis for some elementsconcentration in all areas 
Comparison of the Results of Soil Analysis with Literature Data:

Table 4:-Average soil concentration in ppm for the elements determined in this work compared to the literature data:

\begin{tabular}{|c|c|c|c|c|c|c|}
\hline \multirow[t]{2}{*}{ Element } & \multirow{2}{*}{$\begin{array}{l}\text { This study (All } \\
\text { area) }\end{array}$} & \multicolumn{5}{|c|}{ Previous Studies } \\
\hline & & $\begin{array}{c}\text { Ali } \\
\text { et al.(54) }\end{array}$ & $\begin{array}{l}\text { Ali } \\
\text { et al. } \\
\text { (52) }\end{array}$ & $\begin{array}{c}\text { Wadi } \\
\text { et al. (53) }\end{array}$ & OmotosoandOjo (23) & $\begin{array}{l}\text { Tumukluet } \\
\text { al.(12) }\end{array}$ \\
\hline $\mathrm{Fe}$ & 872520 & $\begin{array}{c}6,355 \text { to } \\
14,635\end{array}$ & - & 2.7521 & - & - \\
\hline $\mathrm{Cu}$ & 19330 & $\begin{array}{l}3.65 \text { to } \\
33.55\end{array}$ & $21-77$ & 0.0435 & 20.66 & 222 \\
\hline $\mathrm{Mn}$ & 11625 & 42 to 655 & & - & 503.43 & 669 \\
\hline $\mathrm{Cr}$ & 1075 & & $11-46$ & 0.4245 & 69.1 & 81 \\
\hline $\mathrm{Ni}$ & 3010 & $\begin{array}{l}(2.5 \text { to } \\
44.95 \\
\end{array}$ & $45-134$ & 0.1331 & 14.4 & 133 \\
\hline $\mathrm{Pb}$ & 80,0150 & $\begin{array}{l}2.65 \text { to } \\
823.5\end{array}$ & $13-33$ & 0.0027 & 13.86 & 267 \\
\hline $\mathrm{Zn}$ & 105.00175 & $\begin{array}{c}11.85 \text { to } \\
40.85\end{array}$ & $14-86$ & 0.0127 & 33.43 & 74 \\
\hline $\mathrm{V}$ & 4755 & - & - & 47.7802 & 84.17 & 178 \\
\hline
\end{tabular}

When the results of the present studycomparedwith results indicated inthe above table $\{3\}$ byinvestigators $\{23,52$, $53,54\}$, high meanconcentration of the all elements in this study wereobserved .

The results of thisstudy also compared with another study reported by Tumukluetal. $\{12\}$, high mean concentration for allelements in this study except $\mathrm{Pb}$ were shown. This differences may be refer to high industrial emission in thepresent study.

\section{Conclusion:-}

The aim of this study was to evaluate the pollution level in four sites(ARS,ECF,ARWandAIA) in Atbara city, Sudan by measuring concentrations of some heavy metals for surface soil samples collected from that area. Concentrations of elements $\mathrm{Fe}, \mathrm{Cu}, \mathrm{Mn}, \mathrm{Cr}, \mathrm{Ni}, \mathrm{Pb}, \mathrm{Zn}$ and $\mathrm{V}$ were determined by using X-MET5000.The data were treated statisticallyby correlation coefficient analysis and multivariate analysis such as, cluster analysis. Strong correlation coefficient between $\mathrm{Mn}-\mathrm{Cr}, \mathrm{Mn}-\mathrm{V}, \mathrm{Ni}-\mathrm{V}, \mathrm{Fe}-\mathrm{Zn}, \mathrm{Mn}-\mathrm{PbandPb}-\mathrm{V}$ were observed. The hierarchical cluster analysis using nearest neighbor method produced two clusters. The first cluster contained $(\mathrm{Pb}, \mathrm{Zn}, \mathrm{Cr}, \mathrm{Ni} \mathrm{V}, \mathrm{Mn}$ and $\mathrm{Cu})$, the second cluster was contained ( $\mathrm{Fe}, \mathrm{Mn}, \mathrm{Cu}$ and $\mathrm{V}$ ). The results of the present study were also compared with previous studies .

\section{References:-}

1. Nimir.S.,A.,M .Environmental Impact of Some Trace ElementsEmission From The Work Environment of AtbaraCement Factory And AtbaraRialwayFoundry.phD Thesis (unpublished) university of Khartoum, Sudan 2006.

2. Najib .N.,A.,Z.; Mohammed.S.,A.; Ismail .S.,H.; WanAhmad.W.,AAssessment of Heavy Metal in Soil due to Human Activities in Kangar , Perlis, Malaysia. International Journal of Civil \& Environmental Engineering,Vol:12 No:06,2012.

3. Khakbaz. P. P.; Mahdeloei. S.; heidari. A. Soil Pollution Control Management Techniques and Methods. Annals of Biological Research, 2012, P (3101-3109).

4. Varsani.A.; Manoj .K. Analysis of Heavy Metals in Soil Samples Collected at three Different Industrial Creeks of Surat, India. .International Journal of Current Microbiology and Applied Sciences ,Volume 4 Number 6 (2015),P(281-286).

5. Mtunzil .F., M.; Dikio.E., D.;Moja. S., J.Evaluatiof of Heavy Metal Pollution on Soil in Vaderbijlpark, South Africa.InternationalJournal of Environmental Monitoring and Analysis, 2015, P (44-49).

6. Suciu .I.;Cosma. C.; Todică.M. ;. Bolboacă .S.,D.; Jäntschi.L.Analysis of Soil Heavy Metal Pollution and Pattern in Central Transylvania. Int. J. Mol. Sci. 2008, P(434-453). 
7. Rajeswari. T., R. ;Sailaja.N.Impact of Heavy Metalson Environmental Pollution.Journal of Chemical and Pharmaceutical Sciences ,2014.

8. Sathyamoorthy.K. ;Sivaruban.T. ; Barathy.S.Assessment Of Heavy Metal Pollution AndContaminates In The Cattle Meat.JrofIndustrial Pollution Control ,2016, P ( 350-355).

9. Ziemacki.G.;Vivano.G.;Merl.F.HeavyMetals :Sources And Environmental Presence.Ann. ${ }^{\text {st }}$.super.Sanita,Vol.25,N.3(1989),P (531-536).

10. Omotoso.O.,A.; Ojo .O.,J. Assessment of Some Heavy Metals Contamination in the Soil of River Niger Floodplain at Jebba, Central Nigeria. Water Utility Journal,P (71-80), 2015.

11. Tumuklu .A .; Yalcin .M.,G .; Sonmez.M . Detection of Heavy Metal Concentrations in Soil. Caused by Nigde City Garbage Dump.Polish J. of Environ. Stud., Vol. 16, No. 4 (2007) ， P (651-658).

12. Ali.I. ,H. ; Ateeg.A.,A. Study of Soil Pollutantsin Omdurman IndustrialArea, Sudan, Using X-ray Fluorescence Technique.Int. J. Environ. Res.,2015,P (291-294,).

13. Wadi1.I.,A.;Dirar. M.; Elhassan.A. Study of Some Heavy Metals and Radioactive Element from Soil Samples, Nyala Area -Sudan.International Journal of Science and Research ,Value (2013).

14. Ali .M.; Elhagwa .A.; Elfaki .J.; Sulieman .M. Influence of the Artisanal Gold Mining on Soil Contamination with Heavy Metals: A case Study From Dar-Mali locality, North of Atbara, River Nile State, Sudan. Eurasian J Soil Sci. 2017, P ( 28 - 36) .

15. Roozbahani.M.,M.;Sobhanardakani.S.; Karimi .H.;Sorooshnia.R,Natural and Anthropogenic Source of Heavy Metals Pollution in the Soil Samples of an Industrial Complex; a Case Study. Iranian Journal of Toxicology ,Volume 9 ,No 29,Summer 2015. 